\title{
Power generation in externally fired air turbine feed by biomass derived syngas
}

\author{
Emanuele Fanelli ${ }^{*}$, Nicola Lovaglio ${ }^{2}$, Giacinto Cornacchia ${ }^{1}$, Giacobbe Braccio ${ }^{4}$, Vinicio Magi ${ }^{5}$ \\ ${ }^{1}$ ENEA - Italian National Agency for New Technologies, Energy and Sustainable Economic Development - S.S. Jonica 106 \\ km 419+500, Rotondella 75026, MT, Italy \\ ${ }^{2}$ University of Basilicata, School of Engineering, Viale dell'Ateneo Lucano, 10, Potenza 85100, Italy
}

Corresponding Author Email: emanuele.fanelli@enea.it

https://doi.org/10.18280/mmc_b.870312

Received: 2 May 2018

Accepted: 12 June 2018

\section{Keywords:}

biomass gasification, downdraft gasifier, externally fired turbine, power generation

\begin{abstract}
In a context where the depletion of traditional energy sources together with the emission reduction question reached a dead end, increasing attention is posed towards emerging technologies. Among such technologies, those for which energy is produced locally by residual biomass have gained in the last decades a role of first relevance. Today, different technologies can be successfully applied for distributed energy production from biomass. Gasification is the most promising because offers the possibility to achieve the highest net efficiency. Nevertheless, several questions need to be addressed to get this technology ready to market. The major drawback is related to the presence, in the produced gas, of tars and condensables that still greatly inhibits the application of this technology. The most common configuration for small scale applications is that where the syngas produced in a downdraft gasifier is feed, after its purification, in an internal combustion engine (ICE) for power production.

In this work, a new configuration where syngas produced by downdraft gasifier is feed directly in an externally fired air turbine is discussed and numerically analysed. A numerical model of the whole process was built using an in-house code and results were evaluated in terms of first law efficiency.
\end{abstract}

\section{INTRODUCTION}

The continuous growth of the worldwide energy demand together the irreversible depletion of traditional fossil fuels, implie to search new ways for energy production and/or conversion. Because of their renewable nature and widespread availability, the use of alternative fuels such as biomass is one of the most promising solution. Today different technologies are available, but among these only those for which energy is produced locally at small scale (below $100 \mathrm{~kW}_{\mathrm{e}}$ ) by residual biomass have gained attention in recent years. In energy production two major aspects are to be taken into account: reduce the costs of production and minimize the effect on environment [1]. To meet these conditions, technologies used must guarantee simpleness in construction, reliable operation, suitability for different kinds of biomass feedstock, acceptable net efficiency and low pollutant emissions [2].

Following the thermochemical conversion pathway, gasification seems to cross better these requirements. This is because gasification implies, for a given biomass power input, lowest dimension in plant development (i.e. size of the reactor, piping and utilities) and highest efficiency in energy conversion. For small-scale distributed power applications (i.e. in the range $10 \mathrm{~kW}-250 \mathrm{~kW}$ ), downdraft gasifiers are considered the most suitable technology because of their intrinsic simple fabrication and operation. In these reactors, biomass is feed at the top while the gasifying medium (air) enters in the troth area where gasification reactions occur. Before enter the gasification zone, biomass is subjected, during its downward pathway, to drying, pyrolysis, oxidation and reduction. The producer gas leaves the reactor at the bottom after going through the high temperature zone in the troth section. This morphological peculiarity of downdraft gasifiers, promotes the high temperature reactions of tar cracking. As consequence of this, the tar content in the producer gas is very low (in the order of $1 \mathrm{~g} / \mathrm{Nm}^{3}$ ). The gas leaving the gasifier is substantially a mixture of combustible $\left(\mathrm{CO}, \mathrm{H}_{2}\right.$ and $\left.\mathrm{CH}_{4}\right)$ and non-combustible $\left(\mathrm{CO}_{2}, \mathrm{~N}_{2}, \mathrm{H}_{2} \mathrm{O}\right)$ molecules in a fraction that is function of the different operational parameters of the process: biomass composition, ER (equivalence ratio), reaction temperature, gasifying agents (air, oxygen enriched air, steam, etc.) and reactor design. Furthermore, these parameters affect the energetic properties (i.e. heating value) and the pollutions content (mainly tars and particulates) of the gas to defining its quality: a good quality syngas has high heating value and low tar content [3].

The syngas leaving the reactor is then purified and it is now ready for applications. Due to its very low heating value, syngas from downdraft gasifier is mainly applied as fuel in internal combustion engines for power production [4] or in gas burner for direct combustion for heat production. Other applications, mainly suitable for very high syngas hydrogen content from steam gasification, are related to the production of hydrogen [5], as fuel in advanced utilities such as gas turbine [6] and fuel cells [7].

Despite the undisputed advantages of downdraft gasifiers, drawbacks such as grate blocking, bridging and channeling are typically found when low bulk density feedstocks are used. Furthermore, downdraft gasifiers are suitable for low moisture content feedstocks, typically below $30 \%$ wt. Higher moisture content affects the syngas quality in term of its heating value and then the gasification cold efficiency. Also tar reduction is 
negatively affected. This is because higher quantities of reaction heat must be devoted to biomass drying reducing consequently the reaction temperature. To remedy this, a series of improvements have been worldwide proposed by researchers at reactor design level. A comprehensive review is reported by [3].

For ICE (Internal Combustion Engine) applications the primary limiting factor in the use of gasification technology and that greatly affect its commercial dissemination, is the syngas tar content. ICE imposes stringent limits in term of syngas contaminants: in addition to the usual ones (sulfur and chloride), below $10-20 \mathrm{mg} / \mathrm{Nm}^{3}$ for both tars and particulate to guarantee long time operation. This requires auxiliary plant equipment such as scrubbers (if wet methods are used) alongside the traditional ones (cyclones, impact filters and dry filter for dust and moisture abatement). To achieve high efficiencies in tar abatement (up to $98 \%$ [8]), usually in the scrubbing section is imposed the use, as washing liquid, of organic solvent such as bio-oil instead of water. Even though these solutions partially allow to meet the stringent limits imposed by ICE, expensive waste disposal procedures are added in the economy of the plant. Bio-oil can be efficiently reused in the system as energy additional source, but generally the excess in mass flow rate at the purge line of the scrubber respect to that where it is used as fuel for power supply, it means a bio-oil accumulation that must be consumed or disposed in other ways. In addition, downdraft to ICE applications imposes continuous adjustment in the engine power rating because of the variation of syngas quality (mainly LHV but also hydrogen to carbon monoxide ratio) as response at any modification of the input operational parameters (such as feedstock size and quality, [9]). Furthermore, the net electrical efficiency by different operational experiences hardly exceeds $18-20 \%$ as reported by [10].

Surely downdraft gasifier coupled to ICE for small plant and distributed power generation is a good choice when residual biomass is available, but the above still unresolved questions, impose an accurate evaluation of the benefits achievable by this practice.

As response to this and to partially overcome the above presented issues, in this study a new configuration is proposed. Syngas by a downdraft gasifier is directly burned at the reactor exit section to heat production. Heat is then used in an external heat exchanger to drive an externally air heated micro-turbine (MT).

This solution allows to mitigate the impact of the gas cleaning section by reducing investment in equipment and operational cost for wastes disposal (ashes, tars, condensates and washing liquids). Furthermore, power production is decoupled by gas quality allowing the use of different material feedstock (compatible with the reactor design) without the need of continuous regulation at the power section. Also, the availability of the power engine is improved by reducing the operative maintenance needs by ICE (oil and filters substitution, piston rings, valves, spark plug, etc.) after few hours of operation $(1000-1500 \mathrm{hr})$. Again, the combustion of syngas instead of biomass in a traditional furnace, implies a reduction in size at the reactor section and in turn in capex and in plant layout development. Drawbacks of this configuration are related at the need of an external high temperature heat exchanger (very expensive) and a more sophisticate control system. Again, the net electrical efficiency, for small scale applications, is in the order of $18-19 \%$ for regenerative heat exchanger layout.

\section{MATHEMATICAL MODEL}

In this section, a detailed description of the comprehensive model used is presented. Each section of the power plant was numerically analysed by using an in-house code developed in Matlab ${ }^{\circledR}$ environment. CoolProop ${ }^{\circledR}$ libraries were instead used to evaluate the main fluid properties as function of the temperature and pressure.

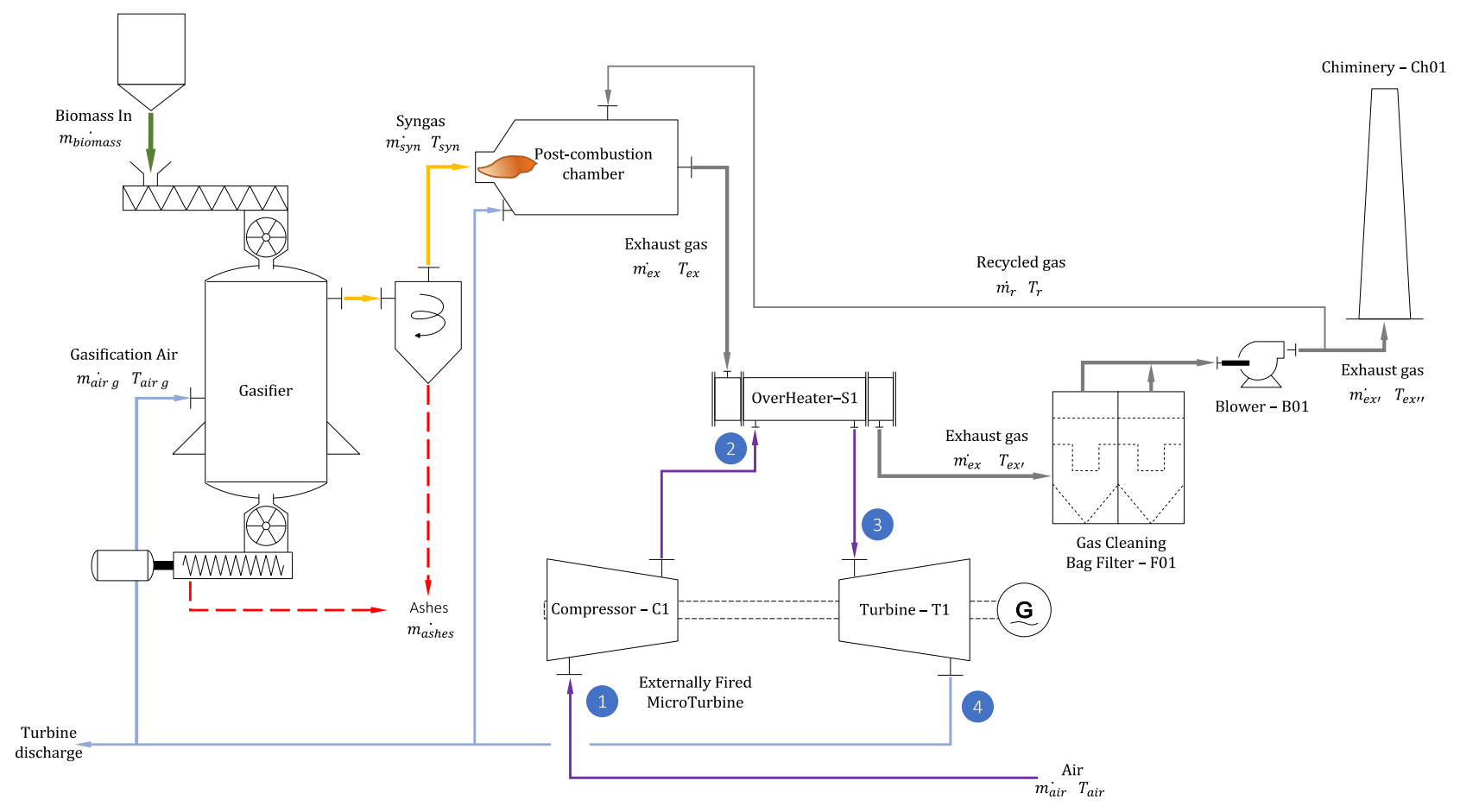

Figure 1. Simple plant layout 
Two configurations were considered: simple and regenerative. In the first one, Figure 1, syngas by downdraft gasifier is directly burned in a post-combustor and hot flue gas was used to drive an externally heated air turbine. Hot air from the turbine discharge section was used to feed the post- combustor to provide the primary combustion air. Hot air was also used as gasifying medium in the gasifier. A fraction of the flue combustion gases was recycled in the post-combustor to control the maximum gas temperature.

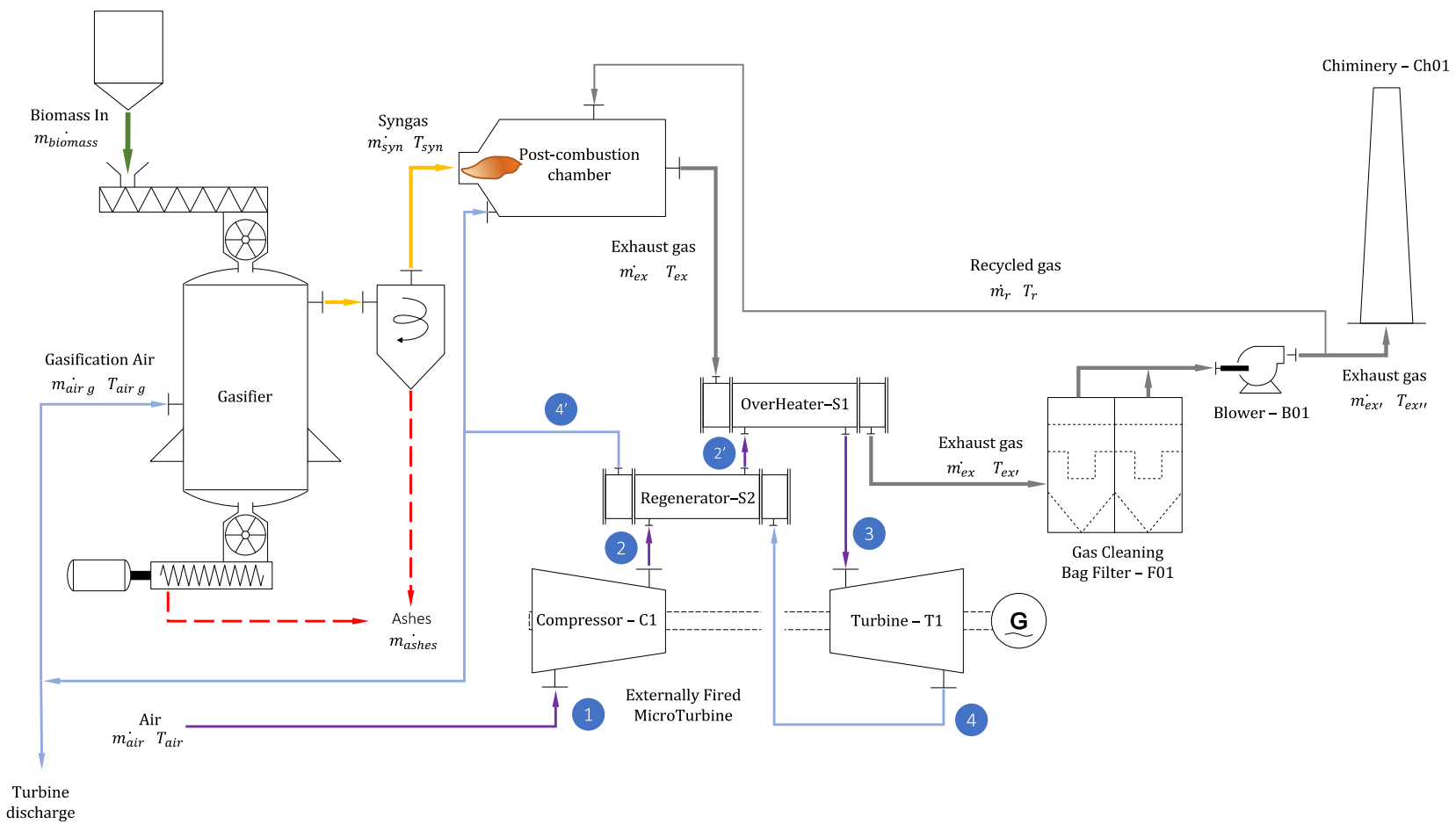

Figure 2. Plant regenerative layout

In the regenerative layout, equipment considered were the same as in the simple plant, Figure 2, with the only difference that hot air from turbine, feeds, in this case, the regenerative section of the heat exchanger to preheat air from the compressor. Follows a description for each sub model here used.

\subsection{Gasification model}

A first approach equilibrium model was used to predict syngas composition and gasification main parameters as function of biomass ultimate analysis, its moisture, gasification agents (air and/or steam) and equivalence ratio.

The main assumption of the equilibrium model is that all reactions reach their thermodynamic equilibrium. In this case it was considered that the pyrolysis products were burnt and equilibrium was achieved in the reduction zone before leaving the reactor as proposed by [11], that both the concentration of tars in producer gas and the heat losses from gasifier to surrounding were negligible as discussed by [12].

The inlet biomass was considered know on the basis of its ultimate analysis and described by the general form $\mathrm{CH}_{a} \mathrm{O}_{b} N_{c}$ where $\mathrm{a}, \mathrm{b}$ and $\mathrm{c}$ are the stoichiometric coefficients evaluated respectively for hydrogen, oxygen and nitrogen. The general gasification reaction can be written as:

$\mathrm{CH}_{\mathrm{a}} \mathrm{O}_{\mathrm{b}} \mathrm{N}_{\mathrm{c}}+\mathrm{w} \mathrm{H} \mathrm{H}_{2} \mathrm{O}+\mathrm{m} \mathrm{O}_{2}+3.76 \mathrm{~m} \mathrm{~N}_{2} \rightarrow \mathrm{x}_{1} \mathrm{H}_{2}+\mathrm{x}_{2} \mathrm{CO}+$

$\mathrm{x}_{3} \mathrm{CO}_{2}+\mathrm{x}_{4} \mathrm{H}_{2} \mathrm{O}+\mathrm{x}_{5} \mathrm{CH}_{4}+(3.76 \mathrm{~m}+\mathrm{c} / 2) \mathrm{N}_{2}$

where $\mathrm{x}_{1} \ldots \mathrm{x}_{5}[\mathrm{kmol}]$ are the five unknown coefficients of products, $\mathrm{w}$ and $\mathrm{m}[\mathrm{kmol}]$ are respectively the total water (biomass moisture and gasifying steam) and oxygen reacted. The biomass moisture content was defined as:

$\mathrm{MC}=\frac{\mathrm{M}_{\mathrm{H}_{2} \mathrm{O}}}{\mathrm{M}_{\text {Biomass ar }}} \cdot 100 \%$

whereas steam to biomass ratio respectively on weight and molar basis, as:

$$
\begin{aligned}
& \left(\frac{S}{B}\right)_{w t}=\frac{M_{\text {steam }}}{M_{\text {Biomass ar }}} \\
& \left(\frac{S}{B}\right)_{\text {mol }}=\left(\frac{S}{B}\right)_{w t} \frac{\mathrm{PM}_{\text {Biomass daf }}}{\mathrm{PM}_{\mathrm{H}_{2} \mathrm{O}}}
\end{aligned}
$$

and consequently $\mathrm{w}$ :

$\mathrm{W}=\frac{\mathrm{PM}_{\mathrm{Biomass} \mathrm{daf}}}{\mathrm{PM}_{\mathrm{H}_{2} \mathrm{O}}} \frac{\mathrm{MC} / 100}{(1-\mathrm{MC} / 100)(1-\mathrm{Ash} / 100)}+\left(\frac{\mathrm{S}}{\mathrm{B}}\right)_{\mathrm{mol}}$

The six unknowns $\mathrm{x}_{1} \ldots \mathrm{x}_{5}$ and $\mathrm{m}$ were evaluated by imposing the mass balance for carbon $\mathrm{C}$, hydrogen $\mathrm{H}$ and oxygen $\mathrm{O}$, the global energy balance and two kinetic equations for methane formation and gas water shift reaction as follows:

$x_{2}+x_{3}+x_{5}=1$

$2 x_{1}+2 x_{4}+4 x_{5}=2 w+a$

$x_{2}+2 x_{3}+x_{4}=w+b+2 m$

Additional two equations can be obtained by considering 
the following reactions occurring in the reduction zone:

$\mathrm{C}+\mathrm{CO}_{2} \leftrightarrow 2 \mathrm{CO}$

$\mathrm{C}+\mathrm{H}_{2} \mathrm{O} \leftrightarrow \mathrm{CO}+\mathrm{H}_{2}$

$\mathrm{C}+2 \mathrm{H}_{2} \leftrightarrow \mathrm{CH}_{4}$

Eq. (9) and (10) can be combined in the whole shift reaction:

$\mathrm{CO}+\mathrm{H}_{2} \mathrm{O} \leftrightarrow \mathrm{CO}_{2}+\mathrm{H}_{2}$

The equilibrium constant for methane formation, Eq. (11), and for the shift reaction, Eq. (12), can be written respectively as:

$\mathrm{K}_{1}=\frac{\mathrm{P}_{\mathrm{CH}_{4}}}{\left(\mathrm{P}_{\mathrm{H}_{2}}\right)^{2}}=\frac{\mathrm{x}_{5} \cdot \mathrm{n}_{\text {tot }}}{\mathrm{x}_{1}^{2}}$

$\mathrm{K}_{2}=\frac{\mathrm{P}_{\mathrm{CO}_{2}} \cdot \mathrm{P}_{\mathrm{H}_{2}}}{\mathrm{P}_{\mathrm{CO}} \cdot \mathrm{P}_{\mathrm{H}_{2} \mathrm{O}}}=\frac{\mathrm{x}_{1} \cdot \mathrm{x}_{3}}{\mathrm{x}_{2} \cdot \mathrm{x}_{4}}$

where $P_{i}$ is the partial pressure of specie $i$, and $n_{\text {tot }}=\sum x_{i}$ is the total mole of the syngas. Equilibrium constants are function of the temperature and can be expressed by means the relation:

$\ln \mathrm{K}_{\mathrm{p}}=\left(-\frac{\Delta \mathrm{G}_{\mathrm{T}}^{\mathrm{o}}}{\mathrm{RT}}\right)$

where the standard Gibbs function of formation as function of the temperature is:

$\Delta \mathrm{G}_{\mathrm{T}}^{\mathrm{o}}=\Delta \mathrm{H}_{\mathrm{T}}^{\mathrm{o}}-\mathrm{T} \Delta \mathrm{S}_{\mathrm{T}}^{\mathrm{o}}$

In the above equation $\Delta \mathrm{H}_{\mathrm{T}}^{\mathrm{o}}$ and $\Delta \mathrm{S}_{\mathrm{T}}^{\mathrm{o}}$ are respectively the enthalpy and entropy change of the reaction. Values for standard Gibbs function and heat of formation at $298.15 \mathrm{~K}$ are collected in Table 1 for the different chemical species here involved. The dependence of the above functions by temperature was evaluated as proposed by the NIST by using data collected in the NIST Database. The general energy balance can be expressed as:

$\mathrm{dH}_{\text {Biomass }}+\mathrm{wdH}_{\mathrm{H}_{2} \mathrm{O}_{\mathrm{l}}}+\left(\frac{\mathrm{s}}{\mathrm{B}}\right)_{\text {mol }} \mathrm{dH}_{\text {Steam }}+\mathrm{mdH}_{\mathrm{O}_{2}}+$

$3.76 \mathrm{~m} \mathrm{dH}_{\mathrm{N}_{2}}=\mathrm{x}_{1} \mathrm{dH}_{\mathrm{H}_{2}}+\mathrm{x}_{2} \mathrm{dH}_{\mathrm{CO}}+\mathrm{x}_{3} \mathrm{dH}_{\mathrm{CO}_{2}}+$

$\mathrm{x}_{4} \mathrm{dH}_{\mathrm{H}_{2} \mathrm{O}_{\mathrm{v}}}+\mathrm{x}_{5} \mathrm{dH}_{\mathrm{CH}_{4}}+(3.76 \mathrm{~m}+\mathrm{c} / 2) \mathrm{dH}_{\mathrm{N}_{2}}$

where $\mathrm{dH}_{\text {any specie }}$ is the sum of the heat formation and the enthalpy change:

$\mathrm{dH}(\mathrm{T})=\mathrm{H}_{\mathrm{f}, 298}^{0}+\Delta \mathrm{H}=\mathrm{H}_{\mathrm{f}, 298}^{0}+\int_{298}^{\mathrm{T}} \mathrm{c}_{\mathrm{p}}(\mathrm{T}) \mathrm{dT}$

The enthalpy change in the above equation can be evaluated by introducing the average specific heat over the temperature change defined as:

$\mathrm{c}_{\mathrm{p}_{\mathrm{mh}}}=\mathrm{R}\left[\mathrm{A}+\mathrm{BT}_{\mathrm{am}}+\frac{\mathrm{C}}{3}\left(4 \mathrm{~T}_{\mathrm{am}}^{2}-\mathrm{T}_{1} \mathrm{~T}_{2}\right)+\frac{\mathrm{D}}{\mathrm{T}_{1} \mathrm{~T}_{2}}\right]$

where $\mathrm{T}_{\mathrm{am}}=\left(\mathrm{T}_{1}+\mathrm{T}_{2}\right) / 2$ is the mean arithmetic temperature, $\mathrm{A}, \mathrm{B}, \mathrm{C}$ and $\mathrm{D}$ are the constants for any chemical species (Table 2) and $\mathrm{R}$ is the universal gas constant.
The heat of biomass formation was evaluated as proposed by [11] considering the follows ideal reactions:

$\mathrm{C}+\mathrm{O}_{2} \rightarrow \mathrm{CO}_{2} \Delta \mathrm{H}_{\mathrm{c}}=-393509$

$\frac{\mathrm{a}}{2} \mathrm{H}_{2}+\frac{\mathrm{a}}{4} \mathrm{O}_{2} \leftrightarrow \frac{\mathrm{a}}{2} \mathrm{H}_{2} \mathrm{O} \quad \Delta \mathrm{H}_{\mathrm{c}}=\frac{\mathrm{a}}{2}(-241818)$

$\mathrm{CO}_{2}+\frac{\mathrm{a}}{2} \mathrm{H}_{2} \mathrm{O} \leftrightarrow \mathrm{CH}_{\mathrm{a}} \mathrm{O}_{\mathrm{b}}+\left(\frac{\frac{\mathrm{a}}{2}-\mathrm{b}+2}{2}\right) \mathrm{O}_{2}$

$\Delta \mathrm{H}_{\mathrm{c}}=\mathrm{HHV}_{\text {Biom }}$

$\mathrm{C}+\frac{\mathrm{a}}{2} \mathrm{H}_{2}+\frac{\mathrm{b}}{2} \mathrm{O}_{2} \leftrightarrow \mathrm{CH}_{\mathrm{a}} \mathrm{O}_{\mathrm{b}} \quad \Delta \mathrm{H}_{\mathrm{f}}^{0}=\sum \Delta \mathrm{H}_{\mathrm{c}, \mathrm{i}}$

Table 1. Gibbs energy function and standard heat of formation at $298.15 \mathrm{~K}$

\begin{tabular}{cccc}
\hline Chemical species & Phase & $\begin{array}{c}\Delta \mathbf{G}_{\mathbf{f}}^{\mathbf{0} 298} \\
{[\mathbf{k J} / \mathbf{k m o l}]}\end{array}$ & $\begin{array}{c}\Delta \mathbf{H}_{\mathbf{f}}^{\mathbf{0}} \mathbf{2 9 8} \\
{[\mathbf{k J} / \mathbf{k m o l}]}\end{array}$ \\
\hline Carbon (Graphite), $\mathrm{C}$ & $\mathrm{s}$ & 0.0 & 0.0 \\
\hline Carbon dioxide, $\mathrm{CO}_{2}$ & $\mathrm{~g}$ & -394359 & -393509 \\
\hline Carbon monoxide, $\mathrm{CO}$ & $\mathrm{g}$ & -137169 & -110525 \\
\hline Hydrogen, $\mathrm{H}_{2}$ & $\mathrm{~g}$ & 0.0 & 0.0 \\
\hline Methane, $\mathrm{CH}_{4}$ & $\mathrm{~g}$ & -50460 & -74520 \\
\hline Oxygen, $\mathrm{O}_{2}$ & $\mathrm{~g}$ & 0.0 & 0.0 \\
\hline Water, $\mathrm{H}_{2} \mathrm{O}$ & $\mathrm{g}$ & -228572 & -241818 \\
\hline Water, $\mathrm{H}_{2} \mathrm{O}$ & $\mathrm{l}$ & -237129 & -285830 \\
\hline
\end{tabular}

The system of non-linear equations was resolved by implementing them in an in-house code developed in Matlab®.

\subsection{Syngas combustion model}

Syngas from gasifier was fed in a post-combustion chamber where it was fully burned. Hot air from the micro turbine section was used as primary combustion air. A portion of cold exhaust gas was recycled to moderate the exit temperature of combustion gas.

Table 2. Heat capacity constants

\begin{tabular}{|c|c|c|c|c|c|}
\hline Chemical species & $\begin{array}{l}\mathbf{T}_{\max } \\
{[\mathbf{K}]}\end{array}$ & $\mathbf{A}$ & $10^{3} B$ & $10^{6} \mathrm{C}$ & $10^{-5} \mathrm{D}$ \\
\hline Carbon, $\mathrm{C}$ & 2000 & 1.771 & 0.771 & - & 0.867 \\
\hline Carbon dioxide, $\mathrm{CO}_{2}$ & 2000 & 5.457 & 1.047 & - & 1.157 \\
\hline $\begin{array}{l}\text { Carbon monoxide, } \\
\text { CO }\end{array}$ & 2500 & 3.376 & 0.557 & - & $\begin{array}{c}- \\
0.031\end{array}$ \\
\hline Hydrogen, $\mathrm{H}_{2}$ & 3000 & 3.249 & 0.422 & - & 0.083 \\
\hline Methane, $\mathrm{CH}_{4}$ & 1500 & 1.702 & 9.081 & $\begin{array}{c}- \\
2.164 \\
\end{array}$ & - \\
\hline Oxygen, $\mathrm{O}_{2}$ & 2000 & 3.639 & 0.506 & - & $-\overline{2}$ \\
\hline Water, $\mathrm{H}_{2} \mathrm{O}$ & 2000 & 3.470 & 1.450 & - & 0.121 \\
\hline
\end{tabular}

Simple stoichiometric relations were used to evaluate the composition of exhaust gas while conservation of mass and energy were imposed to calculate the mass flow rate of the recycled gas for combustion temperature control. By considering syngas composition as input, the following reactions of combustion were considered:

$\mathrm{CO}+\frac{1}{2} \mathrm{O}_{2}+\frac{3.76}{2} \mathrm{~N}_{2} \rightarrow \mathrm{CO}_{2}+\frac{3.76}{2} \mathrm{~N}_{2}$ 
$\mathrm{H}_{2}+\frac{1}{2} \mathrm{O}_{2}+\frac{3.76}{2} \mathrm{~N}_{2} \rightarrow \mathrm{H}_{2} \mathrm{O}+\frac{3.76}{2} \mathrm{~N}_{2}$

$\mathrm{CH}_{4}+2 \mathrm{O}_{2}+2 \cdot 3.76 \mathrm{~N}_{2} \rightarrow \mathrm{CO}_{2}+2 \mathrm{H}_{2} \mathrm{O}+2 \cdot 3.76 \mathrm{~N}_{2}$

Mass flow rate both for exhaust and recycled gas were calculated by imposing the conservation of mass and energy at the post-combustion chamber assumed as control volume in steady state conditions:

$$
\begin{aligned}
& \dot{\mathrm{m}}_{\text {syn }}+\dot{\mathrm{m}}_{\mathrm{air}, \mathrm{c}}+\dot{\mathrm{m}}_{\mathrm{r}}-\dot{\mathrm{m}}_{\mathrm{ex}}=0 \\
& \dot{\mathrm{m}}_{\text {syn }} \mathrm{dh} \mathrm{h}_{\mathrm{syn}}+\dot{\mathrm{m}}_{\mathrm{air}, \mathrm{c}} \mathrm{dh} \mathrm{h}_{\mathrm{air}, \mathrm{c}}+\dot{\mathrm{m}}_{\mathrm{r}} \mathrm{dh} \mathrm{h}_{\mathrm{r}}-\dot{\mathrm{m}}_{\mathrm{ex}} \mathrm{dh}_{\mathrm{r}}-\dot{\mathrm{Q}}_{\text {loss }}=0
\end{aligned}
$$

where $\mathrm{dh}_{\text {any mixture }}$ is the enthalpy change calculated as in Eq. (18).

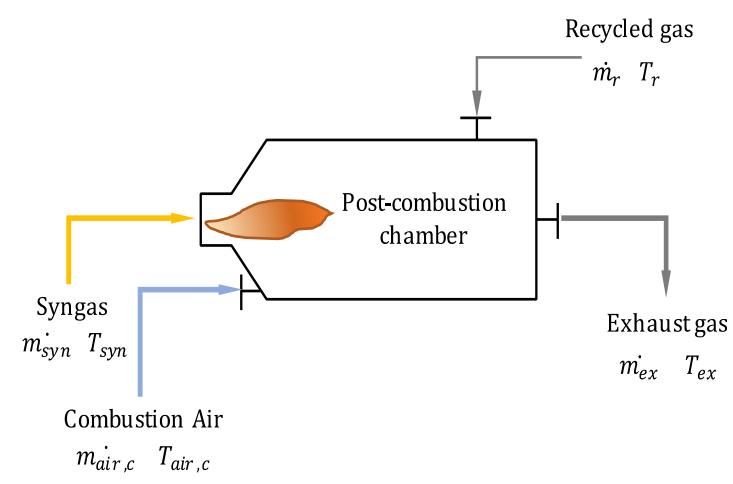

Figure 3. Post-combustion chamber scheme

Properties of the mixtures were calculated by using CoolProp® library once flue gas compositions were known. Thermal losses were imposed to be equal to $2 \%$ of the whole inlet thermal power.

\subsection{Micro turbine thermodynamic model}

Simple thermodynamic model was developed to get evaluations of the main cycle performances. Matlab® was used to implement the mathematical code by using CoolProp ${ }^{\circledR}$ libraries to evaluate fluid properties at each plant sections. With reference to the general scheme of the micro turbine section in regenerative mode depicted in Figure 2, air at conditions of temperature $\mathrm{T}_{1}$ and pressure $\mathrm{p}_{1}$, it is compressed by the compressor $\mathrm{C} 1$. Here an increase both in fluid pressure and temperature respectively to $\mathrm{p}_{2}$ and to $\mathrm{T}_{2}$ is performed. The compression work was evaluated as:

$\dot{W}_{c}=\frac{\dot{m}_{a i r} \cdot\left(h_{2, i s}-h_{1}\right)}{\eta_{i s, c} \cdot \eta_{m, c}} \quad[W]$

where $\eta_{\mathrm{is}, \mathrm{c}}, \eta_{\mathrm{m}, \mathrm{c}}$ are respectively the isentropic and the mechanical compressor efficiencies.

At the regenerator $\mathrm{S} 2$, the heat recovered by the hot air coming from the turbine exit section is used to preheat the same air at the compressor exit section. The recovered heat can be expressed as:

$$
\dot{\mathrm{Q}}_{\mathrm{S} 2}=\left(\mathrm{h}_{2,1}-\mathrm{h}_{2}\right)=\left(\mathrm{h}_{4}-\mathrm{h}_{4,1}\right)[\mathrm{W}]
$$

while that one subtracted at the evaporator S1 from the hot exhaust gases, as:

$\dot{\mathrm{Q}}_{\mathrm{S} 1}=\dot{\mathrm{m}}_{\mathrm{ex}} \cdot\left(\mathrm{h}_{\mathrm{ex}, \mathrm{in}}-\mathrm{h}_{\mathrm{ex}, \mathrm{out}}\right)=\dot{\mathrm{m}}_{\mathrm{air}} \cdot\left(\mathrm{h}_{3}-\mathrm{h}_{2,1}\right)$

Properties at the turbine $\mathrm{T} 1$ inlet section were evaluated once inlet temperature $T_{3}$ and pressure $p_{3}$ of the fluid were known, while the power produced was calculated by imposing the expansion ratio and the isentropic efficiency of the expander.

On the basis of the foregoing assumptions, the electrical power produced was evaluated as:

$\dot{W}_{e l}=\dot{m}_{a i r} \cdot\left(h_{3}-h_{4, i s}\right) \cdot \eta_{i s, t} \cdot \eta_{m, e} \cdot \eta_{e l, g}[W]$

where $\eta_{\text {is,t }}, \eta_{\text {m,e }}$ are respectively the isentropic and the mechanical efficiencies of the expander, while $\eta_{\mathrm{el}, \mathrm{g}}$ is the electrical efficiency of the generator. On the basis of the previous calculations, the first law efficiency was then calculated as following:

$\eta_{\mathrm{I}}=\frac{\dot{\mathrm{W}}_{\mathrm{el}}-\dot{\mathrm{W}}_{\mathrm{c}}}{\dot{\mathrm{Q}}_{\mathrm{S} 1}}$

where required in the mathematical model, the difference of temperature between hot and cold fluids at regenerator S2 and at the evaporator $\mathrm{S} 1$, are fixed. This because in the first approach model developed here, there is no modelling of heat exchangers and so there is no prediction of fluid temperature at the exit sections of the heat exchangers. For the evaluation of the performances of the no regenerative layout, in the previous model it was simple imposed that $h_{2,1}=h_{2}$ so that:

$\dot{\mathrm{Q}}_{\mathrm{S} 1}=\dot{\mathrm{m}}_{\mathrm{ex}} \cdot\left(\mathrm{h}_{\mathrm{ex}, \mathrm{in}}-\mathrm{h}_{\mathrm{ex}, \mathrm{out}}\right)=\dot{\mathrm{m}}_{\mathrm{air}} \cdot\left(\mathrm{h}_{3}-\mathrm{h}_{2}\right) \quad[\mathrm{W}]$

\section{RESULTS}

In this section, main results obtained by mathematical models previously presented are given and discussed in some details. To get a better comprehension of the influence of each operational parameter at sub-system level on the whole plant performances, results by each sub-model are discussed separately. First results by biomass gasification model are analysed in terms of the effects of the main process parameters (mainly biomass moisture and gasification equivalence ratio) on syngas composition, LHV, syngas production rate and gasification cold efficiency. Therefore, follows the micro turbine cycle analysis where the effects of the compression ratio and the inlet turbine temperature on the thermodynamic cycle performances, both for regenerative and no regenerative layout, are discussed. At least the global plant performances are presented in term of the first law efficiency. Main results obtained by the equilibrium gasification model are summarized and presented in the following figures. Simulations were carried out by considering almond shells as biomass. Ultimate analysis and caloric properties are shown in Table 3. The equations presented in sections 2.1 were resolved here by considering the ER (i.e. the air mass flow rate), the biomass composition (and so its moisture), the steam to biomass ratio $\mathrm{S} / \mathrm{B}$ (in the calculations equal to zero, i.e. no additional water other than moisture in the biomass was considered) as main input parameters of the problem. Clearly, in this formulation, the gasification temperature is an unknown of the mathematical problem. 


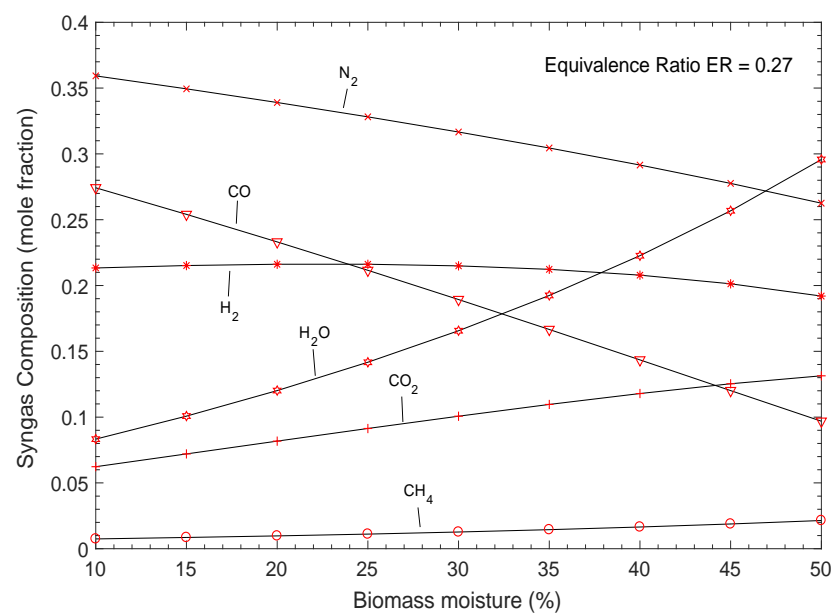

(a)

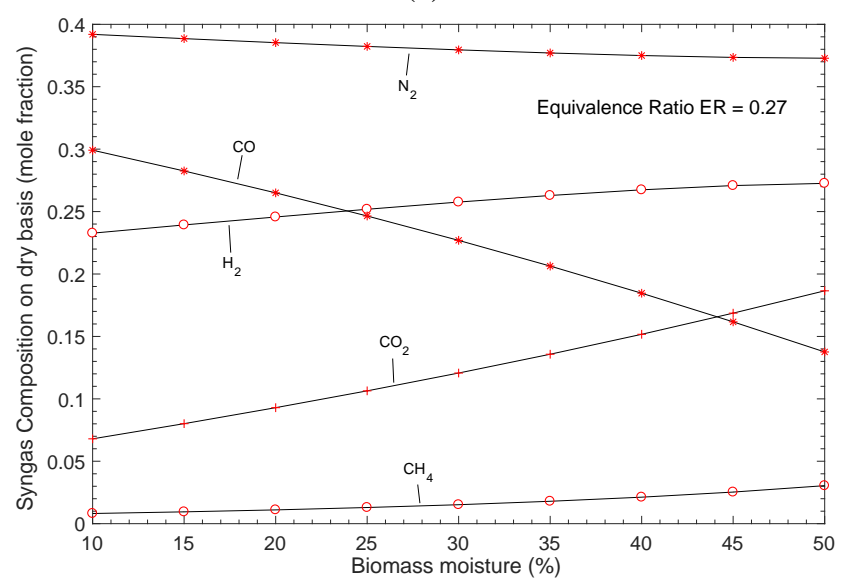

(b)

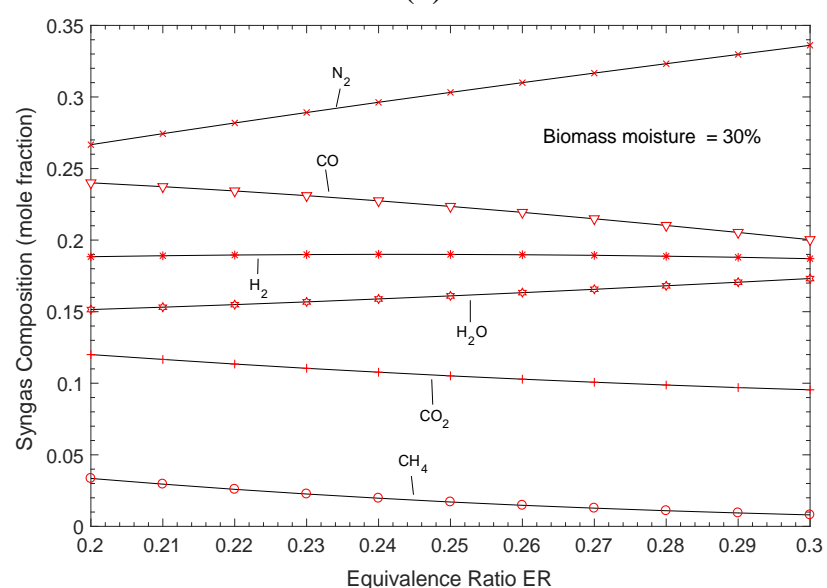

(c)

Figure 4. Syngas composition as function of the biomass moisture at constant equivalence ratio on wet (a) and dry basis (b) and as function of the equivalence ratio at constant biomass moisture (c)

Figure 4 (a) and (b), respectively referred to syngas wet and dry basis, show the effect of biomass moisture on syngas composition.

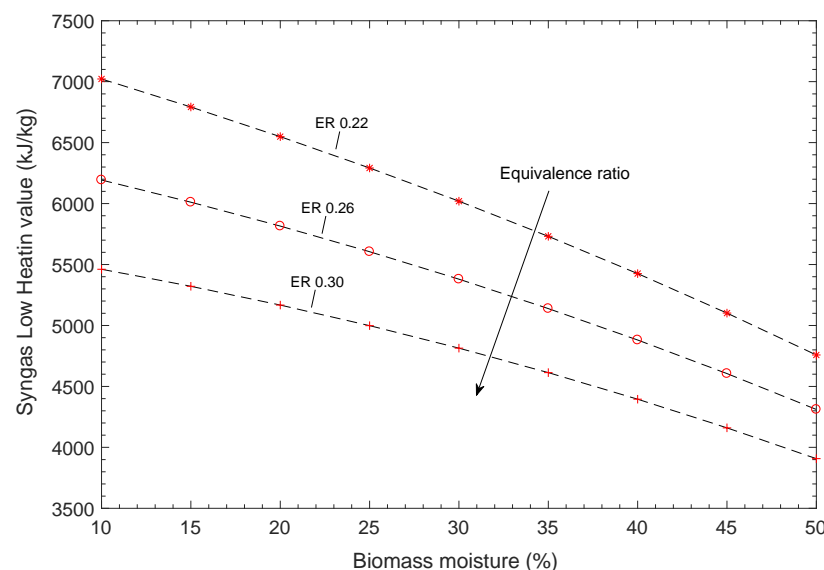

(a)

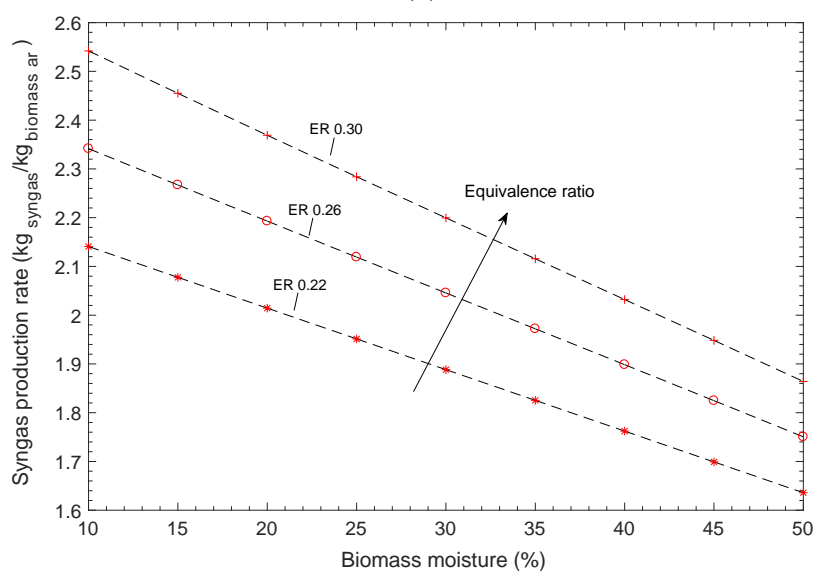

(b)

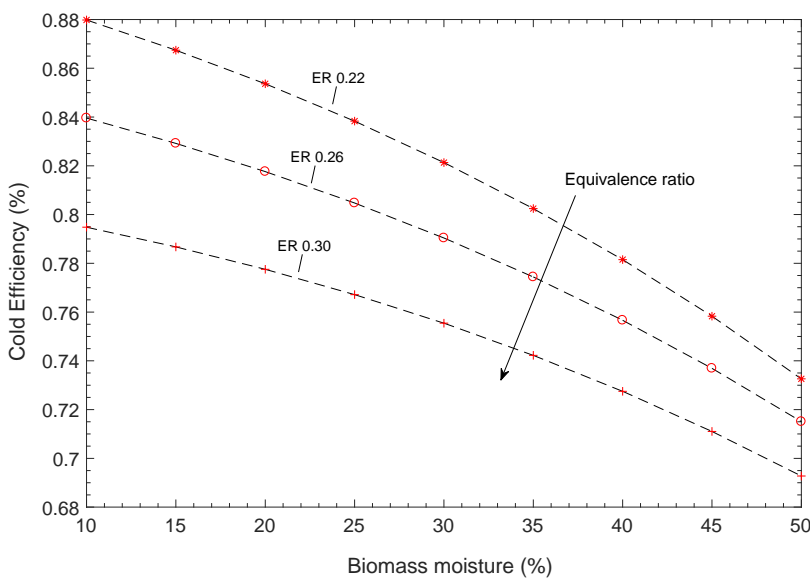

(c)

Figure 5. Syngas low heating value (a), syngas production rate (b) and gasification cold efficiency (c) as function of the biomass moisture and equivalence ratio

As it can be observed, methane concentration is very low: in all cases analysed, below 3\% in mole fraction if referred to dry syngas composition. As biomass moisture increase, hydrogen and methane (this latter in less marked way) contents slightly increase as expected. A similar trend is observed for the carbon dioxide. On the contrary, carbon monoxide monolithically decreases about by the same percentage witch water increases. This is also explicable by the increase in carbon dioxide. Nitrogen content instead, is constant as 
expected (at constant equivalence ratio no more nitrogen is introduced inside the gasifier). At least, Figure 4-(c), shows the influence on syngas composition of the gasification equivalence ratio at constant biomass moisture content $(30 \%$ in the case analysed).

Table 3. Ultimate analysis for biomass material (dry basis, weight percentage), low heating value and moisture of as received matter. Data from ENEA analysis

\begin{tabular}{ccccccc}
\hline \multirow{2}{*}{ Biomass } & \multicolumn{6}{c}{$\%($ w/w dry $)$} \\
\cline { 2 - 7 } & $\mathbf{C}$ & $\mathbf{H}$ & $\mathbf{N}$ & $\mathbf{O}$ & S & Ashes \\
\hline Almond shells & 48.9 & 6.2 & 0.18 & 43.5 & 0.026 & 1.65 \\
\hline
\end{tabular}

\begin{tabular}{ccc}
\hline Biomass & LHV [MJ/kg $\mathbf{d b}]$ & Moisture [\% w/w] \\
\hline Almond Shells & 17.89 & 13.8 \\
\hline
\end{tabular}

As can be noted, as the equivalence ratio increases, all combustible molecules (i.e. hydrogen, methane and carbon monoxide) tend to decrease while, on the contrary, nitrogen increases (much more oxygen is available for combustion reactions and much more nitrogen is introduced in the gasifier with air). This, in last instance, its traduces in a decrease of both in syngas low heating value and in plant cold efficiency as showed in Figure 5 (a) and (c) respectively. On the contrary, due the greater amount of air introduced in the system, syngas production rate increases too, Figure 5-(b).

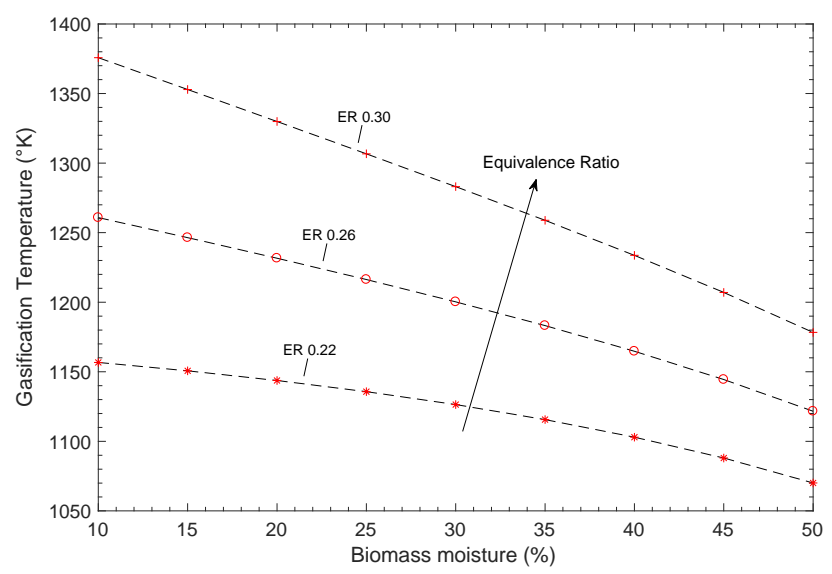

Figure 6. Gasification temperature as function of the biomass moisture and equivalence ratio

The gasification temperature, Figure 6, increases as the biomass moisture decreases and the equivalence ratio increases. This because, in the first case (moisture decrease) more heat is available to be stored in the form of syngas sensible heat, while in the second latter (ER increase), higher temperatures are reached as consequence of the greater amount of combustible molecules burned (much more air is introduced in the gasifier).

Though the true model validation is beyond the purpose of the present work, as reference, in Table 4 experimental data for syngas composition by downdraft gasifier are collected by different authors. As can be noted, the range of variability is very high because of the dependence of syngas composition by a great number of gasifier work conditions and by biomass composition. Anyway, theoretical data obtained by model seem to be in good agreement with experimental ones.
Table 4. Experimental syngas composition from downdraft gasifier. Data collected by different works as reported by [13-

15 ] and confirmed by the thirty years' experience of the ENEA in the gasification field

\begin{tabular}{cc}
\hline Properties & Range (dry basis) \\
\hline $\mathrm{LHV}\left(\mathrm{MJ} / \mathrm{Nm}^{3}\right)$ & $4.0-5.6$ \\
\hline $\mathrm{H}_{2}(\mathrm{vol} \%)$ & $15-21$ \\
\hline $\mathrm{CO}(\mathrm{vol} \%)$ & $10-22$ \\
\hline $\mathrm{CO}_{2}(\mathrm{vol} \%)$ & $11-13$ \\
\hline $\mathrm{CH}_{4}(\mathrm{vol} \%)$ & $1-5$ \\
\hline $\mathrm{C}_{\mathrm{n}} \mathrm{H}_{\mathrm{m}}(\mathrm{vol} \%)$ & $0.5-2$ \\
\hline $\mathrm{N}_{2}(\operatorname{vol} \%)$ & Remaining \\
\hline
\end{tabular}

Main results by micro turbine thermodynamic model are collected in Figure 6, where the influence of the compression ratio and the maximum turbine inlet temperature (TIT) on both cycle first law efficiency and specific work are presented. Data showed are referred to the real thermodynamic cycle behaviour. In the same figure, comparisons between regenerative (grey line) and simple configurations (red line) are presented. As expected, specific work and thus cycle efficiency, both increase as TIT increases. In all cases a maximum is reached for increasing compression ratio as higher is TIT. Such a condition in more evident for simple configuration while for the regenerative one, a nearly independence from compression ratio is observed. In this latter case, maximum is reached in the neighbourhood of $\beta_{c}=2$. For the regenerative configuration, at given TIT, efficiency decreases as pressure ratio increases because of the decreased amount of heat internally regenerated. As shown, regeneration results a thermodynamically beneficial practice up to a certain value of the compression ratio ( $\beta_{\text {lim }}$ ) above witch the efficiency is slightly lower than that evaluated for the simple cycle.
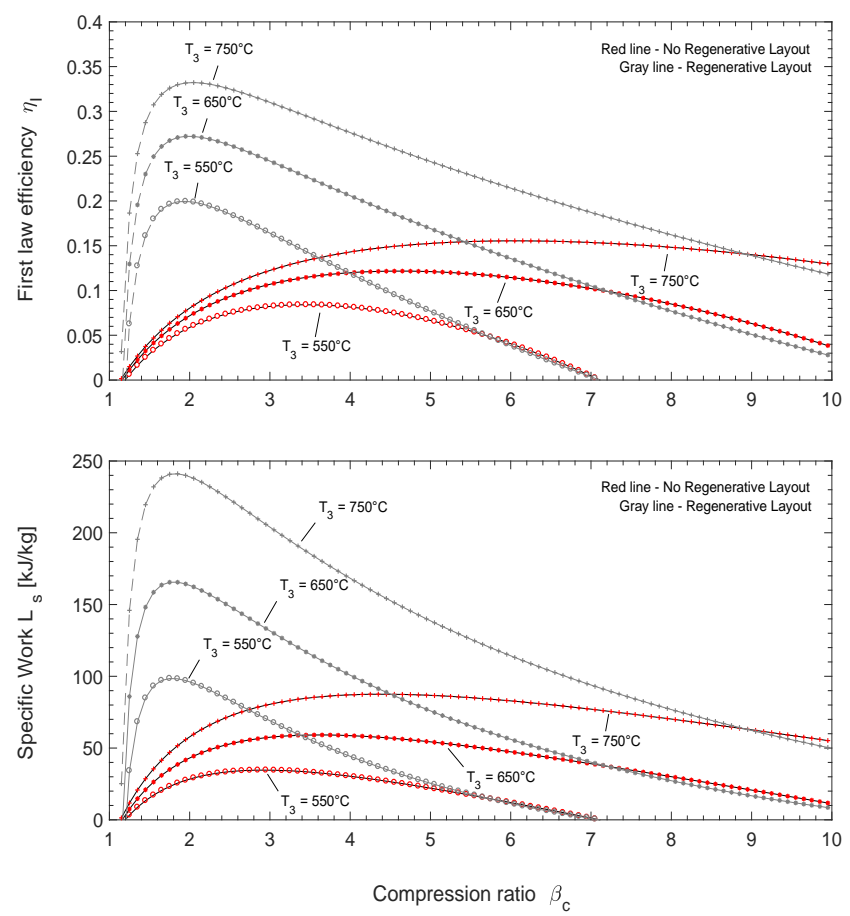

Figure 7. First law efficiency and specific work as function of the compression ratio and the inlet turbine temperature

Figure 7 and Figure 8 show, respectively for the simple (i.e. 
Figure 1) and the regenerative (i.e. Figure 2) plant configurations, the first law efficiency as function of the TIT and the compression ratio at the micro-turbine section.

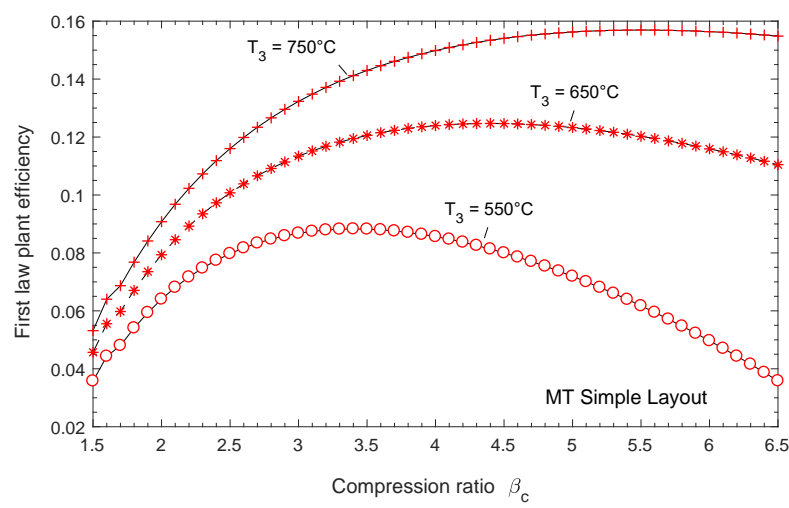

Figure 7. First law efficiency for the simple plant configuration as function of the compression ratio and the inlet turbine temperature

Gasification parameters (i.e. biomass composition and moisture as in Table 3, ER $=0.26$ ) as well as the postcombustion temperature $\left(\mathrm{Tex}=850{ }^{\circ} \mathrm{C}\right.$ ) were kept constant. Main theoretical results at each plant sections as function of the same parameters considered above at the MT, were collected for the regenerative configuration in Table 5. As expected, plant efficiency exhibits a similar trend respect to that of the MT cycle. Also in this case a maximum in plant efficiency was reached approximatively where MT cycle efficiency has a maximum.

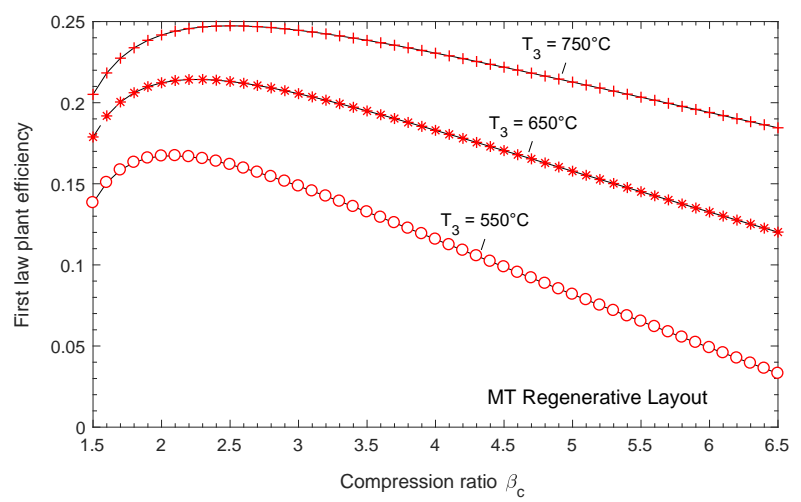

Figure 8. First law efficiency for the regenerative plant configuration as function of the compression ratio and the inlet turbine temperature

As can be noted, plant efficiency for the regenerative configuration is always higher than simple configuration with a peak of about $25 \%$ at TIT $750{ }^{\circ} \mathrm{C}$ and $\beta_{c}$ close to 2.5 . Nevertheless, for those cases where efficiency exceeds $20 \%$, it must be noted that the temperature at the over-heater $\mathrm{S} 1$ hot side outlet section, is on average higher than $450{ }^{\circ} \mathrm{C}$. This means that expensive plant solutions (i.e. high temperature cleaning systems and blowers or alternatively regenerative combustion chamber for the purpose designed) should be adopted. All this could be not economically feasible for small scale applications. Alternatively, simple plant configuration must be considered. In this latter case, acceptable efficiencies (in the order of $16 \%$ ) can be reach at TIT $750^{\circ} \mathrm{C}$ and $\beta_{\mathrm{c}}$ close to 4.5. The challenge is now the high TIT.

Table 5. Main theoretical results by the whole numerical model developed for the regenerative plant configuration

\begin{tabular}{|c|c|c|c|c|c|c|}
\hline \multicolumn{7}{|c|}{ Regenerative plant configuration as shown in Figure 2} \\
\hline \multirow{2}{*}{$\begin{array}{l}\text { Gasification } \\
\text { parameters }\end{array}$} & \multicolumn{6}{|c|}{ Compression Ratio at MT Compressor } \\
\hline & \multicolumn{2}{|c|}{3,5} & \multicolumn{2}{|c|}{4,5} & \multicolumn{2}{|c|}{5,5} \\
\hline 0,26 & \multicolumn{6}{|c|}{ TIT $\left({ }^{\circ} \mathrm{C}\right)$} \\
\hline Moisture & 650 & 750 & 650 & 750 & 650 & 750 \\
\hline \multicolumn{7}{|c|}{ Mass flow rate $(\mathrm{kg} / \mathrm{h})$ : } \\
\hline & \multicolumn{6}{|c|}{ Gasifier } \\
\hline Biomass IN & 89,8 & 71,4 & 102,7 & 76,1 & 120,6 & 82,2 \\
\hline Gasification Air IN & 115,3 & 91,6 & 131,7 & 97,5 & 154,6 & 105,4 \\
\hline Syngas OUT & 205,3 & 163,1 & 234,7 & 173,8 & 275,5 & 187,8 \\
\hline \multirow[t]{2}{*}{ Ashes OUT } & 0,090 & 0,071 & 0,103 & 0,076 & 0,121 & 0,082 \\
\hline & \multicolumn{6}{|c|}{ Post-Combustion chamber } \\
\hline Syngas IN & 205,3 & 163,1 & 234,7 & 173,8 & 275,5 & 187,8 \\
\hline Recycled gas IN & $\begin{array}{c}1741 \\
2\end{array}$ & $\begin{array}{c}1786, \\
3\end{array}$ & $\begin{array}{c}1876 \\
8\end{array}$ & $\begin{array}{c}1729 \\
5\end{array}$ & $\begin{array}{c}2121 \\
7\end{array}$ & $\begin{array}{c}1757, \\
9\end{array}$ \\
\hline Combustion Air IN & 361,5 & 287,2 & 413,4 & 306,2 & 485,7 & 331,0 \\
\hline Exhaust gas OUT & $\begin{array}{c}2308 \\
0\end{array}$ & $\begin{array}{c}2236, \\
6\end{array}$ & $\begin{array}{c}2524 \\
8\end{array}$ & $\begin{array}{c}2209 \\
5\end{array}$ & $\begin{array}{c}2882 \\
9\end{array}$ & $\begin{array}{c}2276, \\
7\end{array}$ \\
\hline \multirow[t]{2}{*}{ Exhaust gas at $\mathrm{CH} 01$} & 566,8 & 450,3 & 648,1 & 479,9 & 761,2 & 518, \\
\hline & \multicolumn{6}{|c|}{ Micro Turbine } \\
\hline AIR IN & $\begin{array}{c}4584, \\
3 \\
\end{array}$ & $\begin{array}{c}3051, \\
7\end{array}$ & \begin{tabular}{|c}
4693 \\
3 \\
\end{tabular} & $\begin{array}{c}2923 \\
4 \\
\end{array}$ & $\begin{array}{c}5142 \\
4 \\
\end{array}$ & $\begin{array}{c}2956, \\
7\end{array}$ \\
\hline \multicolumn{7}{|c|}{ Temperature $\left({ }^{\circ} \mathrm{C}\right)$ : } \\
\hline & \multicolumn{6}{|c|}{ Gasifier } \\
\hline Gasifica & 2,2 & 187,1 & 236,6 & 231,7 & 73,9 & 269 \\
\hline \multirow[t]{2}{*}{ Syngas OUT } & 968,3 & 967,1 & 979,2 & 978,0 & 988,5 & 987, \\
\hline & \multicolumn{6}{|c|}{ Post-Combustion chamber } \\
\hline Syngas IN & 968,3 & 967,1 & 979,2 & 978,0 & 988,5 & 987,3 \\
\hline Recycl & 438,6 & 535,4 & 401,4 & 493,9 & 373,2 & 462, \\
\hline $\mathrm{Comb}$ & 192,2 & 187,1 & 236,6 & 231,7 & 273,9 & 269 \\
\hline \multirow[t]{2}{*}{ Exhaust gas OUT } & 850,0 & 850,0 & 850,0 & 850,0 & 850,0 & 850,0 \\
\hline & \multicolumn{6}{|c|}{ Micro Turbine } \\
\hline Air & 20,0 & 20,0 & 20,0 & 20,0 & 20,0 & 20,0 \\
\hline Compressor OUT $\mathrm{T}_{2}$ & 189,3 & 189,3 & 229,6 & 229,6 & 263,8 & 263,8 \\
\hline S2 Cold side OUT & 423,6 & 520,4 & 386,4 & 478,9 & 358,2 & 447,5 \\
\hline $\mathrm{T}_{3}$ (TIT) & 650,0 & 750,0 & 650,0 & 750,0 & 650,0 & 750,0 \\
\hline Turbine OUT $-\mathrm{T}_{4}$ & 438,6 & 535,4 & 401,4 & 493,9 & 373,2 & 462,5 \\
\hline S2 Hot side OUT T 41 & 192,2 & 187,1 & 236,6 & 231,7 & 273,9 & 269,3 \\
\hline de OUT & 438,6 & 535,4 & 401,4 & 493,9 & 373,2 & 462 , \\
\hline \multicolumn{7}{|c|}{ Main plant performances : } \\
\hline $\mathrm{Q}_{1}$ at $\mathrm{S} 1\left[\mathrm{~kW}_{\mathrm{th}}\right]$ & 334,2 & 250,5 & 396,8 & 278,7 & 479,9 & 311,4 \\
\hline $\mathrm{P}_{\mathrm{el}}[\mathrm{kW} \mathrm{el}]$ & 75,0 & 75,0 & 75,0 & 75,0 & 75,0 & 75,0 \\
\hline & 0,831 & 0,831 & 0,832 & 0,832 & 0,833 & 0,833 \\
\hline$\eta_{\mathrm{I}, \mathrm{MT}}$ & 0,236 & 0,315 & 0,199 & 0,283 & 0,165 & 0,254 \\
\hline$\eta_{I, \text { plant }}$ & 0,195 & 0,245 & 0,170 & 0,230 & 0,145 & 0,213 \\
\hline
\end{tabular}

\section{CONCLUSION}

In this study, a solution where syngas by downdraft gasifier is directly burned to feed an externally fired air turbine was introduced and numerically analysed. Mathematical model of the whole power system was developed by using MatLab® and by implementing CoolProp ${ }^{\circledR}$ library for fluids properties evaluations. Two configurations identified as simple and regenerative were thus compared in terms of the first law efficiency. Results showed that appreciable improvements in plant efficiency can be achieved by using regenerative 
configuration alternatively to simple one. Nevertheless, expensive equipment solutions should be considered to meet the high temperature fluids conditions (greater than $450^{\circ} \mathrm{C}$ ) at the hot side outlet of the over-heater heat exchanger S1. All this makes this configuration supposedly inapplicable for small scale power generation unless to develop alternative and cheaper solutions for the regenerative heat exchanger (i.e. by enclosing the combustion chamber, the high temperature heat exchanger $\mathrm{S} 1$ and the recycling line all in one equipment). Simple layout surely allows for lower efficiencies (in the order of $16 \%$ ) if compared to the regenerative one by using a simpler plant arrangement in terms of utilities and maximum temperatures involved (now the fluid temperature at the hot side outlet of $\mathrm{S} 1$ is in the order of $230^{\circ} \mathrm{C}$ ). Furthermore, also in this case, TIT in the order of $750{ }^{\circ} \mathrm{C}$ requires attentions.

\section{REFERENCES}

[1] Tapas KP, Nimisha KR, Pratik NS. (2016). A comprehensive dynamic model for downdraft gasifier using heat and mass transport coupled with reaction kinetics. $\quad$ Energy 116: 1230-1242. https://doi.org/10.1016/j.energy.2016.10.036

[2] Prakashbhai RB, Raymond LH, Ajay K, Sunil T, Natarianto I. (2018). Scale-up of a downdraft gasifier system for commercial scale mobile power generation. Renewable Energy 118: 25-33 https://doi.org/10.1016/j.renene.2017.11.002

[3] Susastriawana A, Saptoadi H, Purnomo. (2017). Smallscale downdraft gasifiers for biomass gasification: A review. Renewable and Sustainable Energy Reviews (76): 989-1003. http://dx.doi.org/10.1016/j.rser.2017.03.112

[4] González FOC, Mahkamov K, Lora EES, Andrade RV, Jaen RL. (2013). Prediction by mathematical modeling of the behavior of an internal combustion engine to be fed with gas from biomass, in comparison to the same engine fueled with gasoline or methane. Renewable Energy 60 :

427 432.https://doi.org/10.1016/j.renene.2013.05.037

[5] Parthasarathy NKP. (2014). Hydrogen production from steam gasification of - biomass: Influence of process parameters on hydrogen yield - a review. Renewable Energy 66:

570-579. https://doi.org/10.1016/j.renene.2013.12.025

[6] Pedroso DT, Machin EB, Pérez NP, Bollini L, Silveira BJL. (2017). Technical assessment of the Biomass Integrated Gasification/Gas Turbine Combined Cycle (BIG/GTCC) incorporation in the sugarcane industry. Renewable Energy 114: 464-479. https://doi.org/10.1016/j.renene.2017.07.038

[7] Din ZU, Zainal ZA. (2016). Biomass integrated gasification-SOFC systems: Technology overview. Renewable and Sustainable Energy Reviews 53: 13561376. https://doi.org/10.1016/j.rser.2015.09.013

[8] Nakamura S, Yoshikawa K. (2016). Biomass gasification process with the tar removal technologies utilizing biooil scrubber and char bed. Applied Energy 170: 186-192. https://doi.org/10.1016/j.apenergy.2016.02.113

[9] Roy PC, Datta A, Chakraborty N. (2013). An assessment of different biomass feedstocks in a downdraft gasifier for engine application. Fuel 106: 864-868. https://doi.org/10.1016/j.fuel.2012.12.053
[10] Chaves LI, Silva MJ, Souza SNM, et al. (2016). Smallscale power generation analysis: Downdraft gasifier coupled to engine generator set. Renewable and Sustainable Energy Reviews 58: 491-498. https://doi.org/10.1016/j.rser.2015.12.033

[11] Zainal ZA, Ali R, Lean CH, Seetharamu KN. (2001). Prediction of performance of a downdraft gasifier using equilibrium modeling for different biomass material. Energy Conversion and Management 42: 1499-1515.

[12] Jia J, Xu L, Abudula A, Sun B. (2018). Effects of operating parameters on performance of a downdraft gasifier in steady and transient state. Energy Conversion and Management 155: 138-146. http://dx.doi.org/10.1016/j.enconman.2017.10.072

[13] Couto N, Rouboa A, Silva V, Monteiro E, Bouziane K. (2013). Influence of the biomass gasification processes on the final composition of syngas. Energy Procedia 36: 596-606. https://doi.org/10.1016/j.egypro.2013.07.068

[14] Kirsanovs V, Blumberga D, Veidenbergs I, Rochas C, Vigants E, Vigants G. (2017). Experimental investigation of downdraft gasifier at various conditions. Energy Procedia 15: 332-338.

[15] Il Son Y, Jun Yoon S, Ku Kim Y, Goo Lee J. (2011). Gasification and power generation characteristics of woody biomass utilizing a downdraft gasifier. Biomass Bioenergy 35: 4215-4220. https://doi.org/10.1016/j.biombioe.2011.07.008

\section{NOMENCLATURE}

\begin{tabular}{|c|c|}
\hline Ash & Biomass ashes content [\% wt] \\
\hline$\sigma_{m h}$ & Average specific heat $[\mathrm{kJ} / \mathrm{kmol} \mathrm{K}]$ \\
\hline$G_{f 298}^{0}$ & $\begin{array}{l}\text { Standard Gibbs function at } 298.15 \mathrm{~K} \\
{[\mathrm{~kJ} / \mathrm{kmol}]}\end{array}$ \\
\hline$H_{\text {any specie }}$ & $\begin{array}{l}\text { Sum of the heat formation and the enthalpy } \\
\text { change }[\mathrm{kJ} / \mathrm{kmol}]\end{array}$ \\
\hline$H H V_{\text {Biom }}$ & Biomass High Heating Value $[\mathrm{kJ} / \mathrm{kmol}]$ \\
\hline$H_{f, 298}^{0}$ & $\begin{array}{l}\text { Standard heat of formation at } 298.15 \mathrm{~K} \\
{[\mathrm{~kJ} / \mathrm{kmol}]}\end{array}$ \\
\hline$\Delta H_{T}^{o}$ & Enthalpy change of reaction at $\mathrm{T}[\mathrm{kJ} / \mathrm{kmol}]$ \\
\hline $\mathbf{n}$ & Equilibrium constant \\
\hline$L H V_{\text {Biom }}$ & Biomass Low Heating Value $[\mathrm{kJ} / \mathrm{kmol}]$ \\
\hline$m$ & Total oxygen reacted $[\mathrm{kmol}]$ \\
\hline$M$ & Mass $[\mathrm{kg}]$ \\
\hline$M C$ & Moisture content $[\% \mathrm{wt}]$ \\
\hline PM & Molecular weight $[\mathrm{kg} / \mathrm{kmol}]$ \\
\hline$\dot{Q}$ & Thermal power rate $[\mathrm{W}]$ \\
\hline$R$ & Universal gas constant $(8.314 \mathrm{~J} / \mathrm{mol} \mathrm{K})$ \\
\hline$\Delta S_{T}^{o}$ & Entropy change of reaction at $\mathrm{T}[\mathrm{kJ} / \mathrm{kmol} \mathrm{K}]$ \\
\hline & Temperature at turbine inlet \\
\hline & Total water reacted $[\mathrm{kmol}]$ \\
\hline$\dot{W}$ & Mechanical power rate $[\mathrm{W}]$ \\
\hline$x_{5}$ & Stoichiometric coefficients [kmol] \\
\hline
\end{tabular}

Greek symbols

$\begin{array}{ll}\beta_{c} & \text { Compression ratio } \\ \eta_{I} & \text { First law efficiency } \\ \eta_{c} & \text { Gasification cold efficiency }\end{array}$




\section{Subscripts}

air Air

Biomass ar Biomass As Received

Biomass daf c

e

el

$\mathrm{H}_{2} \mathrm{O}$
Compressor

Exit

Electrical

Water 